\title{
INCLUSION OF ENTEROSORBENTS IN ANTI-INFLAMMATORY THERAPY IMPROVE TREATMENT EFFECTIVENESS IN COPD PATIENTS DURING EXACERBATIONS
}

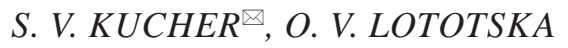 \\ I. Horbachevsky Ternopil National Medical University, Ukraine; \\ 凶e-mail: kuchersv@tdmu.edu.ua
}

Received: 29 January 2021; Accepted: 23 April 2021

\begin{abstract}
Inflammation plays a key role in the development of chronic obstructive pulmonary disease (COPD), and manifests as increased levels of inflammation markers such as cytokines. The purpose of this study was to examine the effect of enterosorbents on IL-1B,TNF- $\alpha$ and IL-10 levels in COPD patients with exacerbations, while taking into account their ages. Patients were divided into two age groups: age group 1 (40-59 years) and age group 2 (>60 years). Levels of IL-1 $1, T N F-\alpha$ and IL-10 were determined by enzyme-linked immunosorbent assay. Levels of pro-inflammatory and anti-inflammatory cytokines were increased in both age groups of COPD patients during exacerbations compared to the healthy control group. Pro-inflammatory cytokines (IL-1 $\beta, T N F-\alpha)$ increased more in age group 2. Basic therapy (BT) had positive impacts. Addition to BT of the enterosorbents Enterosgel and Carboline decreased serum levels of IL-1B,TNF- $\alpha$ and IL-10 in both age groups more than after BT alone. Greater changes were observed in age group 2. We found that addition of the enterosorbents Carboline or Enterosgel to basic therapy of COPD patients during exacerbations decreased levels of IL-1 $\beta, T N F-\alpha$ and IL-10 in patients of both age groups (40-59 years and $>60$ years).
\end{abstract}

Keywords: chronic obstructive pulmonary disease, cytokine, enterosorbents.

\section{Introduction}

Chronic obstructive pulmonary disease (COPD) is associated with chronic inflammation affecting predominantly the lung parenchyma and peripheral airways. Recent studies have shown that this pathology raises the level of many inflammation markers (C-reactive protein, fibrinogen, leukocytes) and pro-inflammatory cytokines $[1,2]$. Implementation of inflammatory reactions is carried out by the mechanisms of the immune system and primarily by cytokines [3]. Cytokines are ubiquitous molecules which act as key messengers for and between immune cells and help to maintain a delicate and intricate balance in the immune system. Such regulation of immune homeostasis is crucial for health and disease, and disruption of this balance results in many chronic pathophysiological states [4]. Cytokines are regulators of host responses to infection, immune responses, inflammation, and trauma. Some cytokines act to make disease worse (pro-inflammatory), whereas others serve to reduce inflammation and promote healing (anti-inflammatory). Attention has also focused on blocking cytokines, which are harmful to the host, particularly during an overwhelming infection. Interleukin (IL)-1 and tumor necrosis factor (TNF) are pro-inflammatory cytokines, and when they are administered to humans, they produce fever, inflammation, tissue destruction, and, in some cases, shock and death [5]. Interleukin 10 (IL-10) is a cytokine with potent anti-inflammatory properties that plays a central role in limiting the host immune response to pathogens, thereby preventing damage to the host and maintaining normal tissue homeostasis [6].

COPD is a common disease in elderly patients. Although COPD is a major cause of respiratory failure and dyspnea in the elderly, multiple other disease entities, including heart failure, pulmonary

(C) 2021 Kucher S. V., Lototska O. V. This is an open-access article distributed under the terms of the Creative Commons Attribution License, which permits unrestricted use, distribution, and reproduction in any medium, provided the original author and source are credited. 
embolism, and anxiety; medication effects; and other conditions, including deconditioning and malnutrition may exacerbate symptoms of this disease [7]. One of the COPD problems is the difficulty of treatment in the elderly. Gradual deterioration of lung function and development of comorbidities can be expected even against the background of optimal COPD treatment. Quite frequently, traditional treatment does not correct, but instead exacerbates the immunocompromised state. Therefore, special attention in geriatric practice should be paid to highly effective drugs with low toxicity that are convenient and easy to use [8]. Such drugs include enterosorbents with different mechanisms of action on the body. Enterosorbents are a group of materials which include activated carbons or charcoals, inorganic minerals, polymeric and silicon-containing resins. More recently they have been termed oral or intestinal adsorbents. The enterosorbent travels along the gastrointestinal tract during which time it can adsorb certain molecules, but it itself is neither absorbed from the gut into the systemic circulation nor metabolized, and thus is excreted unchanged [9].

Systemic (extraintestinal) effects of entersorption are: 1) prevention or attenuation of toxico-allergic reactions; 2) prophylaxis of somatogenic stage of exotoxicosis; 3) decreased metabolic load on excretory and detoxification organs; 4) positive correction of a number of metabolic processes and elements of immune status; 5) improved humoral homeostasis, elimination of imbalance of biologically active compounds; 6) restoration of integrity and penetrability of cell membranes as well as regenerative potential of organs and tissues; 7) suppression of lipid peroxidation (LPO) processes; 8) improvement of lipidogram indexes; and 9) normalization of the serum cytokine profile [10].

The purpose of our study was to examine the effect of enterosorbents on IL-1 $\beta$, TNF- $\alpha$ and IL-10 levels in COPD patients during exacerbations, while taking into account their ages.

\section{Materials and Methods}

The study was carried out on 155 patients with COPD during the exacerbation period who were admitted to the Ternopil City Community Hospital. Among those surveyed, there were 101 men (65.2\%) and 54 women (34.5\%). The mean age was $63.4 \pm 1.0$ years. The disease developed in all patients on the background of long-term smoking. Mean smoking index was 25.89 \pm 3.96 pack-years. The distribution of smoking duration was $19.2 \%$ of patients for $1-9$ years, $21.6 \%$ for $10-19$ years, $23.0 \%$ for $20-29$ years, and $36.2 \%$ for $\geq 30$ years. The research was carried out in accordance with the ethical standards of the responsible committee on human experimentation and with the Helsinki Declaration of 1975, as revised in 2000. This study was approved by the ethics committee of the I. Horbachevsky Ternopil National Medical University, Ternopil, Ukraine (protocol 29, May 20, 2015). The informed consent of each patient was obtained before study enrollment.

The study inclusion criteria were age 40 to 85 years at the time of screening with a diagnosis of COPD in the exacerbation period. The COPD diagnosis was based on medical history, clinical examination, and objective status, as well as radiological and functional diagnostic methods. COPD was diagnosed according to Order 555 of the Ministry of Health (MOH) of Ukraine dated June 27, 2013 [11] and according to the guidelines published by the American Thoracic Society and European Respiratory Society (GOLD, 2013). GOLD classification (2008) was used to assess airway obstruction. The diagnosis of COPD with moderate (stage 2) airway obstruction was made by considering respective clinical features concurrent with restricted airflow, defined as forced expiratory volume in 1 second (FEV1)/forced vital capacity (FVC) ratio less than 0.70 (FEV1/FVC ratio of 50-79\% predicted).

The following study exclusion criteria were used: diabetes mellitus, obesity, acute coronary syndrome, rheumatic pathology, cancer and infectious diseases including viral hepatitis B and C, liver cirrhosis of various etiologies, patients with acute inflammatory processes of any localization, and drug and/or alcohol abuse, as well as other decompensated diseases or conditions that could affect the study results.

The COPD patients were divided into two age groups: age group 1 (90 persons of young and middle age from 40 to 59 years old) and age group 2 (65 elderly and senile patients over 60 years old). The control group had 20 healthy subjects.

Patients of each group received basic therapy (BT) in compliance with the MOH of Ukraine Order No. 555 "Unified clinical protocol of primary, secondary (specialized), tertiary (highly specialized) medical care and medical rehabilitation "Chronic obstructive pulmonary disease" [11]. The BT for COPD in Ukraine includes bronchodilators to relax smooth muscle, such as beta 2-agonists (short and long- 
acting - SABAs and LABAs), inhaled anticholinergic agents (short and long-acting), methylxanthines, inhalation corticosteroids (ICS), combinations of ICS+LABA, mucolytics, antioxidants, and antibiotics in exacerbation of the disease [11].

Each group was distributed across 3 subgroups based on the received treatment (Table 1). In subgroup 1 were 30 patients from age group 1 and 21 from age group 2 , who received only BT. In subgroup 2 were 30 patients from age group 1 and 22 patients from age group 2, who received BT and the enterosorbent "Enterosgel" (see more detailed information below) in the form of a gel (1 tablespoon per os 3 times a day for 10 days, 2 hours before or after meals and medicines). In subgroup 3 were 30 patients from age group 1 and 22 from age group 2, who received BT and the enterosorbent "Carboline" (see more detailed information below) in the form of small granules (1 teaspoon per os, 3 times a day for 10 days, 2 hours before or after meals and medicines).

Enterosorbent Enterosgel is polymethylsiloxane polyhydrate, an organosilicon compound (manufactured by ZAT EOF Kreoma-Pharm, Kyiv, Ukraine) that is an innovative intestinal adsorbent (enterosorbent) that works as a "smart sponge". It comprises microglobules which contain porous spaces filled with water; these aggregate into larger particles $(<250 \mu \mathrm{m}$ in size) forming a hydrogel. The gel is amorphous and insoluble in water. Owing to its gelatinous nature, Enterosgel has a unique porous structure with a specific surface area of 150 $250 \mathrm{~m}^{2} / \mathrm{g}$ dry weight. It has pores in the microporous range (below $2 \mathrm{~nm}$ in diameter) but mostly wide mesopores and small macropores in the range from 2 $\mathrm{nm}$ up to $100 \mathrm{~nm}$ in diameter [10]. The physicochem-

Table 1. Distribution of COPD patients among age groups and treatment subgroups

\begin{tabular}{c|c|c|c}
\hline $\begin{array}{c}\text { Sub- } \\
\text { group }\end{array}$ & $\begin{array}{c}\text { Type of } \\
\text { treatment }\end{array}$ & $\begin{array}{c}\text { Age } \\
\text { group 1 } \\
(40-59 \text { years }) \\
(n=90)\end{array}$ & $\begin{array}{c}\text { Age } \\
\text { group 2 } \\
(>60 \text { years }) \\
(n=65)\end{array}$ \\
\hline 1 & BT & 30 & 21 \\
2 & $\begin{array}{c}\text { BT + } \\
\text { Enterosgel } \\
\text { BT + } \\
\text { Carboline }\end{array}$ & 30 & 22 \\
& 30 & 22 \\
\hline
\end{tabular}

Note. BT - basic therapy ical properties of methylsilicic acid hydrogel determine its adsorptive and protective properties. Firstly, the strong porous structure of the gel-forming matrix determines the adsorption capacity by the mechanism of molecular adsorption and allows the predominant adsorption of medium-molecular size toxic substances and metabolites (for example, bilirubin, protein degradation products). Secondly, due to the gel-like consistency, it adsorbs high-molecular size toxic substances by the mechanism of co-precipitation in the gel (for example, bacterial toxins). Thirdly, Enterosgel also has protective properties. Elastic gel-like particles of this enterosorbent form a layer on the surface of mucous membranes. This layer protects the mucous membranes from the effects of various damaging factors. Finally, compared to carbon enterosorbents, while Enterosgel has a small capacity for adsorbing smaller substances (molecular weight up to $1500 \mathrm{Da}$ ), it is many times superior to them in the ability to bind high molecular weight compounds, including bacterial endotoxin [12].

Enterosorbent Carboline is an inorganic, nonselective, multifunctional, granular fourth generation carbon enterosorbent. It is based on carbon fiber fabric with a specific sorption surface of pores 1 gram per $2500 \mathrm{~m}^{2} / \mathrm{g}$ (for comparison, Enterosgel is 1 gram per $300 \mathrm{~m}^{2}$ ). Carboline (produced by the R.E. Kavetsky Institute of Experimental Pathology, Oncology and Radiobiology, National Academy of Sciences of Ukraine in Kyiv) has pronounced sorption and detoxification properties. In the lumen of the gastrointestinal tract, the carbon fibers bind and remove endogenous and exogenous toxic substances such as antigens, food allergens, drugs and poisons, heavy metal salts, alcohol, and some metabolic products from the body [13].

As markers of the inflammatory process, the serum levels of IL-1 $\beta$, TNF- $\alpha$ and IL-10 (in ng/l) were determined by enzyme-linked immunosorbent assay using a commercial set of reagents ZAT "Vector - Best" (Novosibirsk, Russia) according to the manufacturer's instructions

Sera from patients were obtained from blood samples $(10 \mathrm{ml})$ that were collected in the morning in the fasting state. Serums were stored at $-20^{\circ} \mathrm{C}$. The levels of cytokines in each sample were determined simultaneously. Blood samples were collected before and after treatment (on the 1st day of admission to the hospital and on the $14^{\text {th }}$ day).

Statistical analysis was performed using Microsoft Excel from the Microsoft Office suite of pro- 
grams (namely the Microsoft Excel extension - RealStatistics 2007; Microsoft Corp., Redmond, WA, USA). All data were represented as mean \pm standard error of the mean (mean \pm SEM). Data were analyzed by one-way analysis of variance (ANOVA) followed by the Bonferroni multiple comparison test. A $P \leq 0.05$ was considered to indicate statistical significance [14].

\section{Results and Discussion}

Levels of cytokines in COPD patients during the period of exacerbation were compared with those in the control subjects. Pro-inflammatory and anti-inflammatory cytokine levels were increased in both age groups of COPD patients compared to the control group (Table 2). Pro-inflammatory cytokine (IL-1 $\beta$, TNF- $\alpha$ ) levels were highest in age group 2. In age group 2 before BT, the serum level of IL-1 $\beta$ was 19.4 times greater $(P<0.001)$ and of TNF- $\alpha$ was 4.6 times greater than those in the control group. The serum level of IL-10 in age group 2 was 2.7 times higher than in the control group $(P<0.05)$. In age group 1, higher serum levels of both pro-inflammatory and anti-inflammatory cytokines were also found compared to control subjects. The IL-1 $1 \beta$ level exceeded that in the control group by 10.3 times $(P<0.05)$. There was also an increase in the serum TNF- $\alpha$ level, by 2.6 times $(P<0.05)$. The serum level of IL-10 in age group 1 was 4.7 times higher than in controls $(P<0.05)$.

BT decreased the levels of IL-1 $\beta$ in age group 1 by $23 \%(P<0.05)$, IL-10 by $32 \%(P>0.05)$ and TNF- $\alpha$ by $8 \%(P>0.05)$ compared with pre-treatment levels (Table 3). After BT in age group 2, the concentration of IL-1 $\beta$ significantly decreased by $42 \%(P<0.001)$, of IL-10 by $10 \%(P>0.05)$, and of TNF- $\alpha$ by $33 \%(P<0.001)$ compared with the initial levels.

The next task of our study was to examine the effect of enterosorbents on IL-1 $\beta$, TNF- $\alpha$ and IL-10 levels in COPD patients, while taking into account their ages. The addition of the enterosorbent Enterosgel to BT in COPD patients decreased the levels of cytokines (Table 4).

Ta ble 2. Serum cytokine levels in COPD patients during the exacerbation period before basic therapy

\begin{tabular}{l|c|c|c}
\hline \multicolumn{1}{c|}{ Index } & $\begin{array}{c}\text { Age group 1 (40-59 years) } \\
(n=90)\end{array}$ & $\begin{array}{c}\text { Age group } 2 \\
(>60 \text { years })(n=65)\end{array}$ & Control group $(n=20)$ \\
\hline IL-1 $\beta$, ng/1 & $14.37 \pm 0.96^{\text {a* }}$ & $27.02 \pm 1.21^{*}$ & $1.39 \pm 0.14$ \\
IL-10, ng/1 & $21.83 \pm 2.42^{*}$ & $12.65 \pm 0.78^{*}$ & $4.69 \pm 0.62$ \\
TNF- $\alpha$, ng/1 & $11.07 \pm 0.57^{*}$ & $19.51 \pm 1.08^{*}$ & $4.27 \pm 0.81$ \\
\hline
\end{tabular}

Notes. IL-1 $\beta$ - interleukin-1 beta; IL-10 - interleukin 10; TNF- $\alpha$ - tumor necrosis factor-alpha. *Probability of differences compared to the control group $(P<0.05-0.001)$; ${ }^{a}$ Mean \pm SEM

Ta ble 3. Serum cytokine levels in COPD patients during the exacerbation period before and after basic therapy

\begin{tabular}{|c|c|c|c|}
\hline \multicolumn{2}{|r|}{ Index } & Age group 1 (40-59 years) $(n=30)$ & Age group $2(>60$ years) $(n=21)$ \\
\hline \multirow[t]{3}{*}{ IL-1 $\beta, n g / 1$} & before treatment & $14.37 \pm 0.96^{\mathrm{a}}$ & $27.02 \pm 1.21$ \\
\hline & after BT treatment & $11.00 \pm 1.36$ & $15.65 \pm 1.31$ \\
\hline & $P$ & $<0.05$ & $<0.001$ \\
\hline \multirow[t]{3}{*}{ IL-10, ng/1 } & before treatment & $21.83 \pm 2.42$ & $12.65 \pm 0.78$ \\
\hline & after BT treatment & $14.76 \pm 1.54$ & $11.42 \pm 0.84$ \\
\hline & $P$ & $>0.05$ & $>0.05$ \\
\hline \multirow[t]{3}{*}{ TNF- $\alpha, n g / 1$} & before treatment & $11.07 \pm 0.57$ & $19.51 \pm 1.08$ \\
\hline & after BT treatment & $10.23 \pm 0.96$ & $13.00 \pm 1.28$ \\
\hline & $P$ & $>0.05$ & $<0.001$ \\
\hline
\end{tabular}

Notes. BT - basic therapy; IL-1 $\beta$ - interleukin-1 beta; IL-10 - interleukin 10; TNF- $\alpha$ - tumor necrosis factor-alpha. $P$ - probability of differences between the groups before and after BT; ${ }^{\mathrm{a}}$ Mean $\pm \mathrm{EM}$ 
After treatment with BT and Enterosgel, serum levels of IL- $1 \beta$ in age group 1 decreased by $49 \%$ and in age group 2 by $62 \%(P<0.001)$. Serum IL10 levels also decreased, by 44 and $16 \%(P>0.05)$, respectively. Treatment with $\mathrm{BT}$ and Enterosgel in COPD patients led to decreased serum TNF- $\alpha$ levels of $29 \%$ in age group 1 and $48 \%$ in age group 2 $(P<0.001)$.

The addition of the enterosorbent Carboline to BT in of COPD patients during exacerbations decreased serum levels of IL-1 $\beta$ and IL-10 in age group 1 both by 59\% $(P<0.001)$ and in age group 2 by $64 \%(P<0.001)$ and $17 \%(P>0.05)$, respectively (Table 5). Serum levels of TNF- $\alpha$ decreased by $42 \%$ $(P<0.001)$ in age group 1 and by $52 \%(P<0.001)$ in age group 2 .

We conclude that in our study, COPD patients of both age groups during exacerbations had higher serum levels of IL-1 $\beta$, IL-10 and TNF- $\alpha$ than control group subjects (Figs. 1, 2).

Comparing the two age groups, we found that levels of pro-inflammatory cytokines IL-1 $\beta$ and TNF- $\alpha$ in age group 2 were higher by 1.9 and 1.8 times $(P<0.05)$, respectively, than those in

Ta b le 4. Serum cytokine levels in COPD patients during the exacerbation period before and after treatment with basic therapy and Enterosgel

\begin{tabular}{|l|c|c|c|}
\hline \multicolumn{2}{|c|}{ Index } & $\begin{array}{c}\text { Age group } 1 \\
\text { (40-59 years) }(n=30)\end{array}$ & $\begin{array}{c}\text { Age group 2 } \\
(>60 \text { years })(n=22)\end{array}$ \\
\hline \multirow{3}{*}{ IL-1 $\beta, n g / 1$} & $14.37 \pm 0.96^{\mathrm{a}}$ & $27.02 \pm 1.21$ \\
\cline { 2 - 4 } & before treatment & $7.29 \pm 0.89$ & $10.25 \pm 0.86$ \\
\cline { 2 - 4 } & $P$ & $<0.001$ & $<0.001$ \\
\hline \multirow{3}{*}{ IL-10, ng/1 } & before treatment & $21.83 \pm 2.42$ & $12.65 \pm 0.78$ \\
\cline { 2 - 4 } & after treatment with BT + Enterosgel & $12.20 \pm 1.50$ & $10.57 \pm 1.07$ \\
\cline { 2 - 4 } & $P$ & $>0.05$ & $>0.05$ \\
\hline \multirow{3}{*}{ TNF- $\alpha, n g / 1$} & before treatment & $11.07 \pm 0.57$ & $19.51 \pm 1.08$ \\
\cline { 2 - 4 } & after treatment with BT + Enterosgel & $7.83 \pm 0.53$ & $10.07 \pm 1.04$ \\
\cline { 2 - 4 } & $P$ & $<0.01$ & $<0.001$ \\
\hline
\end{tabular}

Notes. BT - basic therapy; IL-1 $\beta$ - interleukin-1 beta; IL-10 - interleukin 10; TNF- $\alpha$ - tumor necrosis factor-alpha. $P$ - probability of differences between the groups before and after BT + Enterosgel treatment; ${ }^{\mathrm{a}}$ Mean $\pm \mathrm{SEM}$

Ta ble 5. Serum cytokine levels in COPD during the exacerbation period before and after treatment with basic therapy and Carboline

\begin{tabular}{|l|c|c|c|}
\hline \multicolumn{2}{|c|}{ Index } & $\begin{array}{c}\text { Age group 1 } \\
\text { (40-59 years) }(n=30)\end{array}$ & $\begin{array}{c}\text { Age group 2 } \\
(>60 \text { years })(n=22)\end{array}$ \\
\hline \multirow{3}{*}{ IL-1 $\beta, \mathrm{ng} / 1$} & before treatment & $14.37 \pm 0.96^{\mathrm{a}}$ & $27.02 \pm 1.21$ \\
\cline { 2 - 4 } & after treatment with BT + Carboline & $5.87 \pm 0.83$ & $9.62 \pm 0.99$ \\
\cline { 2 - 4 } & $P$ & $<0.001$ & $<0.001$ \\
\hline \multirow{3}{*}{ IL-10, ng/1 } & before treatment & $21.83 \pm 2.42$ & $12.65 \pm 0.78$ \\
\cline { 2 - 4 } & after treatment with BT + Carboline & $8.97 \pm 1.09$ & $10.45 \pm 1.06$ \\
\cline { 2 - 4 } & $P$ & $<0.001$ & $>0.05$ \\
\hline \multirow{3}{*}{ TNF- $\alpha, \mathrm{ng} / 1$} & before treatment & $11.07 \pm 0.57$ & $19.51 \pm 1.08$ \\
\cline { 2 - 4 } & after treatment with BT + Carboline & $6.45 \pm 0.64$ & $9.39 \pm 1.15$ \\
\cline { 2 - 4 } & $P$ & $<0.001$ & $<0.001$ \\
\hline
\end{tabular}

Notes. BT - basic therapy; IL-1 $\beta$ - interleukin-1 beta; IL-10 - interleukin 10; TNF- $\alpha$ - tumor necrosis factor-alpha. $P$ - probability of differences between the groups before and after BT + Carboline treatment; ${ }^{a}$ Mean \pm SEM 


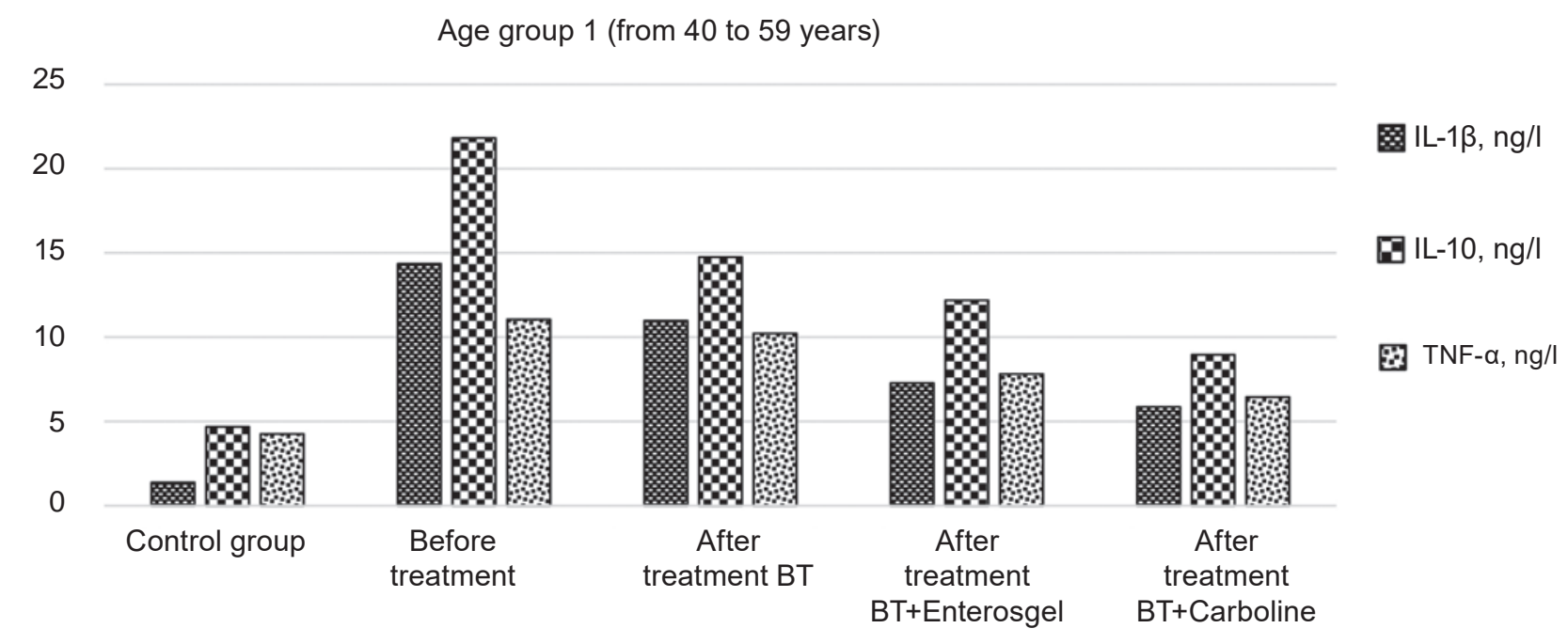

Fig. 1. Serum cytokine levels in COPD patients of age group 1 during exacerbations before and after treatment. BT-basic therapy; IL-1 $\beta$ - interleukin-1 beta; IL-10 - interleukin 10; TNF- $\alpha$ - tumor necrosis factoralpha

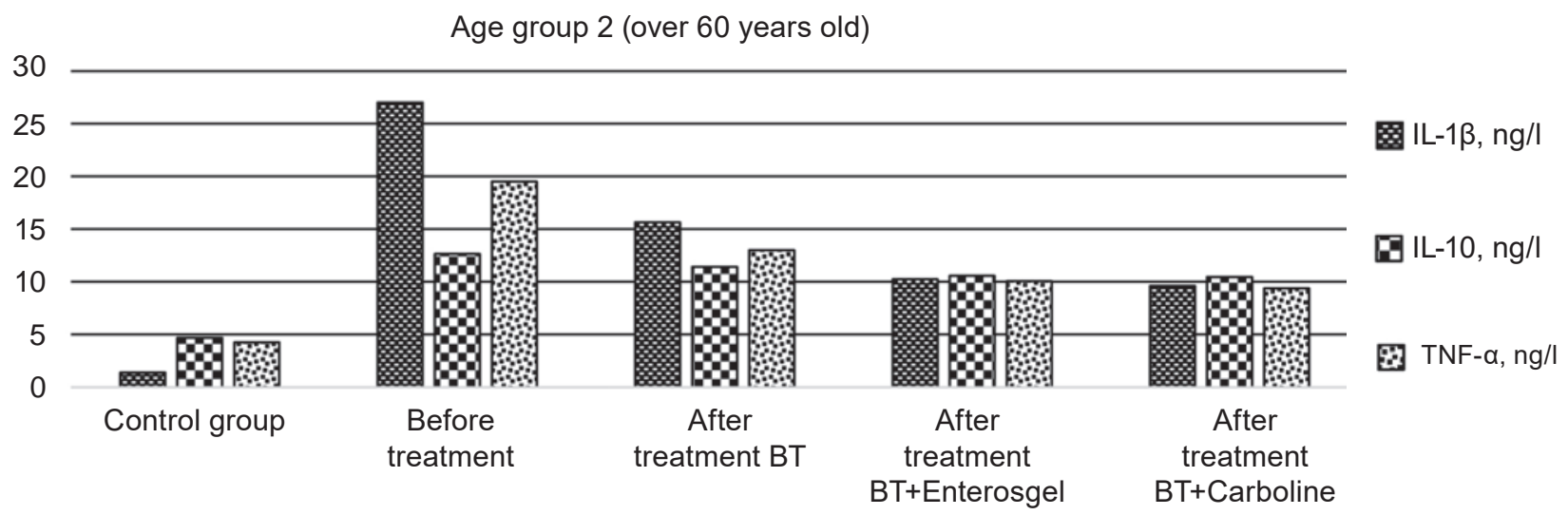

Fig. 2. Serum cytokine levels in COPD patients of age group 2 during exacerbations before and after treatment. BT - basic therapy; IL-1 $\beta$ - interleukin-1 beta; IL-10 - interleukin 10; TNF- $\alpha$ - tumor necrosis factoralpha

age group 1. These indexes indicate a pronounced activity of the inflammatory process in COPD patients over 60 years old. According to a review of the literature, high activity of pro-inflammatory cytokines may inhibit the synthesis of IL-10 [15]. The level of anti-inflammatory cytokine IL-10 in age group 2 was 1.7 times lower than in age group 1 . The results of our studies are consistent with the data of other authors, who after a comprehensive examination of patients, concluded that at the beginning of COPD there is a predominance of pro-inflammatory cytokines of macrophage origin over regulatory cytokines. This may be the body's response to an antigenic stimulus, which aims to limit the inflammatory process by creating conditions for the formation of a protective fibrin barrier. A significant increase in these cytokine levels in serum (IL- $1 \beta, \mathrm{TNF}-\alpha$ ) is likely to predict the risk of bronchial obstruction development or progression [16].

The effects of BT and the enterosorbents Carboline and Enterosgel on cytokine levels in COPD patients were studied at 14 days after beginning treatment, while taking into account the patients' ages. As shown in Figs. 1 and 2, cytokine levels were reduced in both age groups due to these treatments. Our findings concur with other scientific works $[10,17]$. BT in age group 1 decreased levels of IL-1 $\beta$ by $23 \%$, IL-10 by $32 \%(P>0.05)$ and TNF- $\alpha$ by $8 \%$ $(P>0.05)$ compared with pre-treatment indexes of COPD patients with exacerbations. The addition of 
enterosorbents to BT of in patients with COPD exacerbations decreased serum levels of IL-1 $\beta$, IL-10 and TNF- $\alpha$ in both age groups more than after treatment with BT alone (Figs. 1, 2). The use of BT with Enterosgel in age group 1 decreased serum levels of IL-1 $\beta$ by $49 \%(P>0.05)$, IL-10 by $44 \%(P>0.05)$ and TNF- $\alpha$ by $29 \%(P<0.001)$. The addition of Carboline to BT decreased the serum levels of IL-1 $\beta$ and IL-10 in age group 1 both by $59 \%(P<0.001)$, and levels of TNF- $\alpha$ by $42 \%(P<0.001)$.

Greater changes were observed in age group 2 . After BT serum levels of IL- $1 \beta$ significantly decreased by $42 \%$, IL-10 by $10 \%(p>0.05)$ and TNF- $\alpha$ by $33 \%(p<0.001)$ compared with the initial indicators. The addition of Enterosgel to BT in age group 2 decreased serum levels of IL-1 $\beta$ by $62 \%$ $(P<0.001)$, IL-10 by $16 \%(P>0.05)$ and TNF- $\alpha$ by $48 \%$ ( $P<0.001)$. The used of BT with Carboline decreased serum levels of IL-1 $\beta$ and IL-10 in age group 2 by $64 \%(P<0.001)$ and $17 \%(P>0.05)$, respectively, and of TNF- $\alpha$ by $52 \%(P<0.001)$.

The observed changes in the cytokine status of these patients can be explained by the fact that enterosorbents adsorb toxic metabolites in the intestine, have hepatoprotective and antioxidant effects, significantly improve cellular and humoral immunity, and reduce sensibilization. Several cytokines, like IL-1 and TNF- $\alpha$, play key roles in mediating acute inflammatory reactions, either in a native or transformed form through the secretions of the mucous membrane, liver and pancreas into the lumen of the alimentary canal, from where they can be absorbed into the blood again. Thus, after passing through the phases of biotransformation, endogenous toxic substances are distributed between the blood, tissues and the enteric system by mass transfer pathways. The accumulation of these ingredients in the body leads to endotoxicosis.

One of the safest and highly effective methods for removing toxic substances is enterosorption. It is based on oral administration of medications capable of adsorbing various toxic substances of endogenous and exogenous origin in the digestive canal without entering into chemical reactions with them. Decreasing the level of pro-inflammatory cytokines under the influence of enterosorbents, according to literature review, has been observed in cases of thermal trauma, food allergy, intestinal infection and measles, and pancreonecrosis, and creates opportunities for effective use of enterosorbents in a number of other clinical situations including anticancer chemotherapy [10].
For reducing cytokine levels in COPD patients, in addition to BT we used two enterosorbents - Enterosgel and Carboline. While they have different mechanisms of enterosorption, they have the same beneficial characteristics [17]: high efficiency due to their large active surface areas, which makes it possible to administer moderate rather than high doses during therapy; high sorption capacity in relation to toxins of protein and lipoprotein origin; proven safety record during use including no damage to the mucous membranes of the gastrointestinal tract, and no toxic or allergic properties; high selectivity with minimal loss of essential micronutrients; insoluble, do not absorb and do not have systemic effects; neutral taste (are without flavoring or aromatic additives), do not cause nausea or vomiting; convenient release form and dosage that can be used either in a hospital setting or at home.

Conclusions. We found that addition of the enterosorbents Carboline or Enterosgel to basic therapy of COPD patients during exacerbations decreased levels of IL-1 $\beta$, TNF- $\alpha$ and IL-10 in patients of both age groups ( $40-59$ years and $>60$ years).

Conflict of interest. Authors have completed the Unified Conflicts of Interest form at http://ukrbiochemjournal.org/wp-content/uploads/2018/12/ coi_disclosure.pdf and declare no conflict of interest.

Funding. The studies were conducted within the framework of the research work of the Ternopil National Medical University named after I. Horbachevsky Ministry of Health of Ukraine "Comorbid conditions in the clinic of internal diseases: predictors of development, early diagnosis, prevention and treatment”, state registration number 0113U001244.

\section{ВКЛЮЧЕННЯ ЕНТЕРОСОРБЕНТІВ ДО ПРОТИЗАПАЛЬНОЇ ТЕРАПІЇ ДЛЯ ПОЛІПШЕННЯ ЕФЕКТИВНОСТІ ЛІКУВАННЯ ХВОРИХ НА ХОЗЛ У ГОСТРІЙ ФАЗІ}

\author{
С. В. Кучер ${ }^{\bowtie}$, О. В. Лотоиька \\ Тернопільський національний \\ медичний університет \\ імені І. Я. Горбачевського МОЗ України \\ ๒e-mail: kuchersv@tdmu.edu.ua
}

Ключову роль у розвитку хронічної обструктивної хвороби легенів (ХОЗЛ) відіграє запалення, яке проявляється підвищеним рівнем таких маркерів запалення, як цитокіни. Ме- 
тою цього дослідження було вивчити вплив ентеросорбентів на рівень цитокінів IL-1 $\beta, \mathrm{TNFa}$ та IL-10 у хворих на ХОЗЛ у період загострення з урахуванням віку пацієнта. Пацієнтів було розподілено за двома віковими групами: група 1 (від 40 до 59 років), група 2 (старше 60 років). Рівень IL-1 $\beta$, TNF- $\alpha$ та IL-10 визначали методом імуноензимного аналізу. Рівень прозапальних та протизапальних цитокінів збільшувався в обох вікових групах хворих на ХОЗЛ у період загострення порівняно 3 групою здорових людей. Базова терапія (БТ) мала позитивний вплив. Приєднання до БТ ентеросорбентів Ентеросгелю та Карболайну зменшувало рівень IL-1 $\beta$, IL-10 та TNF- $\alpha$ в сироватці крові пацієнтів обох груп більше, ніж у разі застосування лише БТ. Вираженіші зміни спостерігались у пацієнтів вікової групи 2. Показано, що включення ентеросорбентів Карболайн або Ентеросгель до базової терапії хворих на ХОЗЛ із загостренням знижувало рівень IL1, TNF- $\alpha$ та IL10 у пацієнтів будь-якого віку.

К л ю ч о в і с л о в а: хронічна обструктивна хвороба легень, цитокіни, ентеросорбенти.

\section{References}

1. Barnes PJ. Inflammatory mechanisms in patients with chronic obstructive pulmonary disease. $J$ Allergy Clin Immunol. 2016; 138(1): 16-27.

2. Su B, Liu T, Fan H, Chen F, Ding H, Wu Z, Wang H, Hou S. Inflammatory Markers and the Risk of Chronic Obstructive Pulmonary Disease: A Systematic Review and Meta-Analysis. PLoS One. 2016; 11(4): e0150586.

3. Perret J, McDonald C, Apostolopoulos V. Elevated serum interleukin-5 levels in severe chronic obstructive pulmonary disease. Acta Biochim Biophys Sin (Shanghai). 2017; 9(6): 560-563.

4. Gulati K, Guhathakurta S, Joshi J, Rai N, Ray A. Cytokines and their Role in Health and Disease: A Brief Overview. MOJ Immunol. 2016; 4(2): 00121.

5. Dinarello CA. Proinflammatory cytokines. Chest. 2000; 118(2): 503-508.

6. Iyer SS, Cheng G. Role of interleukin 10 transcriptional regulation in inflammation and autoimmune disease. Crit Rev Immunol. 2012; 32(1): 23-63.

7. Fried TR, Vaz Fragoso CA, Rabow MW. Caring for the older person with chronic obstructive pulmonary disease. JAMA. 2012; 308(12): 12541263.

8. Voronina LP. Obstructive lung disease in the practice of a geriatrician. Med Novosti. 2014; (3): 17-22. (In Russian).

9. Howell CA, Mikhalovsky SV, Markaryan EN, Khovanov AV. Investigation of the adsorption capacity of the enterosorbent Enterosgel for a range of bacterial toxins, bile acids and pharmaceutical drugs. Sci Rep. 2019; 9(1): 5629.

10. Shevchuk OO, Posokhova EA, Sakhno LA, Nikolaev VG. Theoretical ground for adsorptive therapy of anthracyclines cardiotoxicity. Exp Oncol. 2012; 34(4): 314-322.

11. Unified clinical protocol of primary, secondary (specialized), tertiary (highly specialized) medical care and medical rehabilitation "Chronic obstructive pulmonary disease" Order of the Ministry of Health of Ukraine from 27.06.2013 № 555 [Electronic resource]. Regime of access : http://mtd.dec.gov.ua/images/ dodatki/2013_555_HOZL/2013_555hozl_ ykpmd.pdf (In Ukrainian).

12. Nikolaev VG. Enterosgel. K.: Bogdana, 2009: 159 p. (In Russian).

13. Practical recommendations for the use of granular carbon enterosorbents "Carboline": methodical recommendations / Nikolaev VG, Andreychin MA, Bardakhivska KI, Sakhno LO, Kopcha VS, Yushko LO, Nikolaeva VV, Ivanyuk AA, Shevchuk OO / RE Kavetsky Institute of Experimental Pathology, Oncology and Radiobiology, National Academy of Sciences of Ukraine. K.: IEPOR NASU, 2013. 16 p. (In Ukrainian).

14. Rebrova OYu. Statistical analysis of medical data. Application of Statistica software package. M.: MediaSphere, 2006. 312 p. (In Russian).

15. Delieva A, Dolinina L, Trofimov V. The level of anti-inflammatory cytokine IL-10 in patients with chronic obstructive pulmonary disease of varying severity. Eur Respir J. 2013; 42(Suppl 57): P600.

16. Colarusso C, Terlizzi M, Molino A, Pinto A, Sorrentino R. Role of the inflammasome in chronic obstructive pulmonary disease (COPD). Oncotarget. 2017; 8(47): 81813-81824.

17. Konorev MR. Clinical pharmacology of enterosorbents of new generation. Vestnik Farmatsii. 2013; (4(62)): 79-85. (In Russian). 